\title{
Characteristics of Riverbank Communities in Dealing With Floods
}

\author{
Eka Mutia, Ellida Novita Lydia*, Firdasari \\ Civil Engineering Study Program, Faculty Engineering \\ Universitas Samudra \\ Langsa, Indonesia \\ *ellidanovita@unsam.ac.id
}

\begin{abstract}
Floods are one of the natural disasters often experienced by people in Indonesia, especially those who live on the riverbank. The riverbank areas are identified as slum settlements that have irregular settlement patterns. People who live in flood-prone areas have a high level of danger and have different characteristics and affect levels of the community prepared in dealing with floods. The research objective was to determine the correlation between the characteristics of the community and the knowledge, attitudes, and actions of the people along the river during a flood. The research was conducted by taking samples using purposive sampling. The level of public understanding of what to do when a flood occurs is $\mathbf{7 2 . 5 8 \%}$, meaning that people have good knowledge about floods. Level of understanding of the actions that must be taken before the flood was only $45.71 \%$. Characteristics of riverbank communities in dealing with floods have a positive correlation value. The riverbank community's understanding of floods was more based on their experiences so far with floods.
\end{abstract}

Keywords-flood, characteristics, riverbanks

\section{INTRODUCTION}

Development is an activity that continues following human needs and activities. Uncertain development planning, demographic and environmental changes have put some cities at high risk of disasters. Unplanned expansion of development results in reduced green open space [1]. Located in the tropics, Indonesian cities are vulnerable to hydrometeorological disasters such as floods and landslides, thus impacting climate change [2]

Based on data from the Indonesian National Disaster Management Agency, natural disasters occurred in Indonesia from January to June 2020 as many as 1,549 times, and 99\% of them are hydrometeorological. Of these events, 620 floods occurred $(40.03 \%)$. This data explains that flooding is one of the natural disasters that is often experienced by people in Indonesia [3] especially those who live along rivers such as the Krueng Langsa river, Aceh. The riverbank areas are identified as slum settlements that have irregular settlement patterns inadequate housing conditions make these settlements unable to survive when a flood occurs [4]. People who live in floodprone areas have a high level of danger and have different characteristics and affect the level of community preparedness in facing flood disasters [5].

Given these conditions, communities should have flood preparedness and adaptation strategies in anticipation of frequent disasters. Motoyoshi, community perception and level of understanding of flood disaster preparedness is an important part of flood management [3]. A Perceived vulnerability to future adverse weather events, social connectedness, and selfefficacy significantly predicted part of the variance in disaster preparedness behavior. People who often experience floods will do the same for every flood disaster that happens regardless of the level of danger predicted [6]. People along the river have strong social ties that they feel safe living in floodprone areas [7].

This research was conducted in the Krueng Langsa riverbank area, namely in the Gampong Jawa in Langsa Kota District, Seulalah Baro, and the Pondok Pabrik in Langsa Lama District, Langsa City. The research objective was to determine the correlation between the characteristics of the community and the knowledge, attitudes, and actions of the people along the river during a flood. The research was conducted by taking samples using purposive sampling.

\section{METHODS}

\section{A. Study Area}

The research was carried out against the population living on the Krueng Langsa Riverbank Langsa City, Aceh Province, Indonesia. The research focused on Langsa Kota and Langsa Lama sub districts. In this sub-district, there are several villages located on the riverbank and every year experienced flood disasters, namely Gampong Jawa, Seulalah Baru, and Pondok Pabrik. It is also a densely populated area.

\section{B. Research Design}

The research was conducted by distributing questionnaires to the family heads living on the riverbanks (Table 1) and analyzed quantitatively. Purposive sampling techniques with community criteria for sample purposes are people who have experienced floods and live on the Krueng Langsa riverbank. 
Characteristics of the people studied were demographic factors such as gender, age, education level, income, and type of occupation (Widiyaningrum [5] and [8]). Community readiness in the face of flooding is measured based on [3]:

- Knowledge of flooding (factors causing flooding, evacuations to be carried out, and risks that occur when flooding)

- Attitudes during floods (actions and mitigations that must be taken in the event of a flood)

- Actions in the event of flooding (evacuation methods and actions are taken to reduce flood risk)

- Actions before flooding (insurance preparation and simulation of floods)

\section{RESULTS AND DISCUSSION}

\section{A. Families Affected by the Flood}

The largest number of families affected by the flood was in Gampong Jawa, to be precise in the sub-village of Jawa Rear 1, totaling 250 families (31\% of 807 families). the number of families affected by flooding at the research location can be seen in Table 1 below:

TABLE I. TOTAL FAMILIES AFFECTED BY THE FLOOD

\begin{tabular}{|c|l|l|l|}
\hline \multirow{2}{*}{ Village } & \multirow{2}{*}{ Hamlet } & \multicolumn{2}{c|}{ Families affected by the Flood } \\
\cline { 3 - 4 } & & Number of families & Percent \\
\hline \multirow{4}{*}{ Gampong Jawa } & Jawa Belakang 1 & 250 & 31 \\
\cline { 2 - 4 } & Jawa Belakang 2 & 18 & 2 \\
\cline { 2 - 4 } & Amaliah & 71 & 9 \\
\cline { 2 - 4 } & Jawa Baru & 175 & 22 \\
\hline \multirow{3}{*}{ Gampong Jawa } & Cendana & 83 & 10 \\
\cline { 2 - 4 } & Melati & 35 & 4 \\
\cline { 2 - 4 } & Kenanga & 120 & 2 \\
\hline \multirow{3}{*}{ Pondok Pabrik } & Nuri 1 & 20 & 2 \\
\cline { 2 - 4 } & Nuri 2 & 20 & 100 \\
\cline { 2 - 4 } & Garuda & 15 & \\
\hline Total & & 807 & 2 \\
\hline
\end{tabular}

Based on the table above respondents were selected as many as 89 family heads from 807 families (calculated using the Slovin formula) to be sampled in this study.

\section{B. Community Readiness in Dealing with Floods}

Community readiness in dealing with floods should be seen, in the following table:

TABLE II. COMMUNITY READINESS IS FACING FLOODS

\begin{tabular}{|l|l|l|l|}
\hline \multirow{2}{*}{ No } & \multirow{2}{*}{ Indicator } & \multicolumn{2}{|c|}{ Readiness Rate (\%) } \\
\cline { 3 - 4 } & & Ready & Not Ready \\
\hline 1 & Knowledge of floods & 81.42 & 18.58 \\
\hline 2 & Actions when a flood occurs & 72.58 & 27.42 \\
\hline 3 & Actions before the flood & 45.71 & 54.29 \\
\hline
\end{tabular}

In the table above, the level of knowledge about floods reaches $81.42 \%$, meaning that the community has a good understanding of flooding. The level of public knowledge of what to do when a flood occurs is $72.58 \%$, meaning that people have good knowledge about floods. The level of understanding of what to do before the flood was only $45.71 \%$. From the data, the communities on the riverbanks have good knowledge of flooding and understand what actions to take when floods. The weakness is that the residents do not understand what to do before the flood disaster strikes.

Based on the attitude of the community in dealing with floods, based on the figure 1 below:

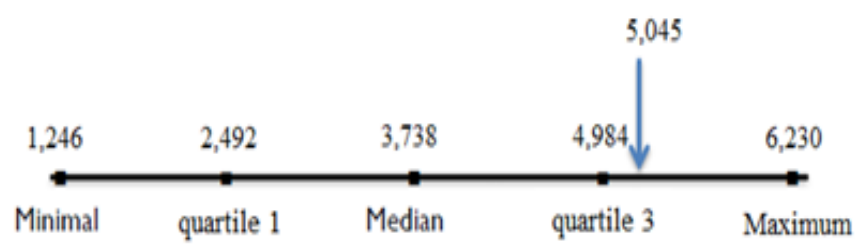

Fig. 1. Community attitudes in facing floods.

The total value of community attitudes in dealing with floods is 5,045. This value falls between the 3rd quartile and the maximum value. This shows that the attitude of the communities on the Krueng Langsa riverbank in dealing with floods is very good.

\section{Correlation between Age and Community Readiness}

The results of the correlation between age and community readiness in dealing with floods as a whole have a low positive correlation value. Only pre-flood and pre-flood measures in the age group over 60 years have a high positive correlation value, as shown in Table 3. It shows that length of stay and life experience play a more important role when facing floods.

Parents have more life experience so they are judged to have a wise attitude in predicting self-preparation for disasters will be dealing in the future. However, parents should be given an understanding of the importance of disaster preparedness and disaster risk reduction [9].

TABLE III. CORRELATION BETWEEN AGE AND COMMUNITY READINESS

\begin{tabular}{|l|l|l|l|l|l|}
\hline \multirow{2}{*}{ No } & \multirow{2}{*}{ Age Group (years) } & \multicolumn{4}{|c|}{ Correlation Value } \\
\cline { 3 - 6 } & & Knowledge & Attitude & Ready & Not Ready \\
\hline 1 & $21-40$ & 0.329 & 0.174 & 0.026 & 0.260 \\
\hline 2 & $41-60$ & 0.114 & 0.331 & 0.109 & 0.057 \\
\hline 3 & $>60$ & 0.081 & 0.082 & 0.771 & 0.826 \\
\hline
\end{tabular}

\section{Correlation between Gender and Community Readiness}

Gender has a positive correlation with people's dealing with face flooding. However, based on Table 4, men have a better correlative relationship and are more alert in action and knowledge about floods.

It can be said that both men and women must be equipped with knowledge about flood disasters both during pre-disaster, during the disaster, and before the disaster by the Ministry of Public Works Regulation No. PSN. 08 of 2012 [10]. 
TABLE IV. GENDER CORRELATION AND COMMUNITY READINESS

\begin{tabular}{|l|l|l|l|l|l|}
\hline \multirow{2}{*}{ No } & \multirow{2}{*}{ Gender } & \multicolumn{4}{|c|}{ Correlation Value } \\
\cline { 3 - 6 } & & Knowledge & Attitude & Ready & Not Ready \\
\hline 1 & Woman & 0.091 & 0.086 & 0.142 & 0.003 \\
\hline 2 & Man & 0.394 & 0.059 & 0.217 & 0.093 \\
\hline
\end{tabular}

\section{E. Correlation of Education Level and Community Readiness}

The relationship between education level and community readiness in dealing with floods has a positive value. The level of diploma education and above has better preparedness to face disasters. Knowledge of disasters is so important because preparing the community for dealing, includes emergency management procedures, assessing hazards, vulnerabilities and risks. We also need to plan an emergency operation, develop a warning system identity and obtain resources and grants, instituting mutual assistance agreements, practice, train, and educate people [11].

TABLE V. CORRELATION BETWEEN EDUCATION LEVEL AND COMMUNITY READINESS

\begin{tabular}{|l|l|l|l|l|l|}
\hline \multirow{2}{*}{ No } & \multirow{2}{*}{ Gender } & \multicolumn{4}{|c|}{ Correlation Value } \\
\cline { 3 - 6 } & & Knowledge & Attitude & Ready & Not Ready \\
\hline 1 & Primary School & 0.266 & 0.030 & 0.084 & 0.353 \\
\hline 2 & Junior high school & 0.100 & 0.204 & 0.028 & 0.136 \\
\hline 3 & Senior High School & 0.100 & 0.068 & 0.184 & 0.013 \\
\hline 4 & > Diploma & 0.408 & 0.548 & 0.307 & 0.219 \\
\hline
\end{tabular}

\section{F. Correlation of Job Types and Community Readiness}

The strong correlation between the type of work and the readiness community is on attitudes, but the types of entrepreneurial work and others show a low positive correlation. However, the type of labor work and the action during the flood has a correlation value of 0 (no relationship), as seen in Table 6.

Overall other occupations have the highest number in the study area, so it can be said that the correlation between work and community readiness along the riverbanks has a weak positive value. It means that the type of work does not affect the readiness of the local community.

TABLE VI. CORRELATION OF TYPES OF WORK AND COMMUNITY READINESS

\begin{tabular}{|l|l|l|l|l|l|}
\hline \multirow{2}{*}{ No } & \multirow{2}{*}{ Level of education } & \multicolumn{4}{|c|}{ Correlation Value } \\
\cline { 3 - 6 } & & Knowledge & Attitude & Ready & Not Ready \\
\hline 1 & Labourer & 0.700 & 0.857 & 0.000 & 0.346 \\
\hline 2 & Contract employees & 0.259 & 0.828 & 0.517 & 0.900 \\
\hline 3 & $\begin{array}{l}\text { Government } \\
\text { Employees }\end{array}$ & 0.018 & 0.689 & 0.205 & 0.654 \\
\hline 4 & Entrepreneur & 0.505 & 0.248 & 0.142 & 0.192 \\
\hline 5 & Other & 0.097 & 0.058 & 0.053 & 0.130 \\
\hline
\end{tabular}

\section{G. Correlation of Income Levels and Community Readiness}

The higher the level of people's income, the better the correlation value. Table 7 shows that the income level is above Rp. 3,000,000,-, has a very high positive correlation to knowledge about floods. Besides, attitudes and actions that be taken also have a high positive correlation value. It is inversely proportional to the income level below Rp. 1,500,000,-, has a weak positive correlation value, especially on knowledge.

TABLE VII. CORRELATION OF TYPES OF WORK AND COMMUNITY READINESS

\begin{tabular}{|l|l|l|l|l|l|}
\hline \multirow{2}{*}{ No } & \multirow{2}{*}{ Income } & \multicolumn{4}{|c|}{ Correlation Value } \\
\cline { 3 - 6 } & & Knowledge & Attitude & Ready & Not Ready \\
\hline 1 & $<1,500,000$ & 0.001 & 0.003 & 0.317 & 0.083 \\
\hline 2 & $\begin{array}{l}1,5000,001- \\
3,000,000\end{array}$ & 0.196 & 0.437 & 0.377 & 0.075 \\
\hline 3 & $>3,000,000$ & 1,000 & 0.629 & 0.707 & 0.502 \\
\hline
\end{tabular}

\section{CONCLUSION}

Based on the results of research, analysis, and discussion, it can conclude that the characteristics of the Krueng Langsa riverbank community in dealing with floods have a positive correlation value, but more only have a weak positive correlation value and the understanding of the Krueng Langsa riverbank community about flood disasters is more based for their experience so far in the flood disaster that occurred in Langsa City.

\section{ACKNOWLEDGMENT}

The authors gratefully acknowledge that the present research was supported by LPPM and PM of Universitas Samudra through Penelitian Dasar Unggulan (PDU) with contract number 517/UN54.6/PG/2020.

\section{REFERENCES}

[1] S. Pokhrel, "Green space suitability evaluation for urban resilience: an analysis of Kathmandu Metropolitan city, Nepal," Environ. Res. Commun., vol. 1, no. 10, p. 105003, 2019.

[2] I.S. Fitrinitia, P. Junadi, E. Sutanto, D.A. Nugroho, A. Zubair, and E. Suyanti, "Local adaptive capacity as an alternative approach in dealing with hydrometeorological risk at Depok Peri-Urban City," IOP Conf. Ser. Earth Environ. Sci., vol. 129, no. 1, 2018.

[3] S. Maryati, S. Eraku, and M. Kasim, "Perceptions and adaptation strategies of the community against flood risk at the estuary riverbank of Bone River, Gorontalo Province," IOP Conf. Ser. Earth Environ. Sci., vol. 235 , no. $1,2019$.

[4] W.J. Mononimbar, "Slum upgrading based on flood mitigation for resilience of Manado City,” IOP Conf. Ser. Earth Environ. Sci., vol. 179, no. 1,2018

[5] R. Kumalawati, "Pengaruh Karakteristik Masyarakat Terhadap Kesiapsiagaan pada Daerah Bahaya Banjir di Kecamatan Pandawan Kabupaten Hulu Sungai Tengah Kalimantan Selatan," in Prosiding Seminar Nasional Geografi UMS Upaya Pengurangan Risiko Bencana Terkait Perubahan Iklim, 2016, pp. 462-471, 2016.

[6] K. Kanakis and C.J. McShane, "Preparing for disaster: Preparedness in a flood and cyclone prone community," Aust. J. Emerg. Manag., vol. 31, no. 2, pp. 18-24, 2016.

[7] B.S. Waloejo, I.R.D Ari, M. Anggraeni, D.M. Zakiyah, and R. Alfiah, "Role of social media towards flood disaster adaptation in Bojonegoro 
region of East Java, Indonesia," IOP Conf. Ser. Earth Environ. Sci., vol. 202, no. $1,2018$.

[8] R. Nurhaimi A and S. Rahayu, "Kajian Pemahaman Masyarakat Terhadap Banjir di Kelurahan Ulujami, Jakarta,” Tek. PWK, vol. 3, no. 2, pp. 351-358, 2014.

[9] O.S. Hardi, D. Darsihardjo, E. Ningrum, and N. Nandi, "Geographic Skills of Elementary School Students in Solving Emergency Flood
Response Problems," IOP Conf. Ser. Earth Environ. Sci., vol. 145, no. 1, 2018

[10] Menteri Pekerjaan Umum, Peraturan Menteri Pekerjaan Umum Republik Indonesia Nomor 23/PRT/M/2015 tentang Pengelolaan Aset Irigasi. Indonesia, 2015.

[11] D.A. McEntire and A. Myers, "Preparing communities for disasters: Issues and processes for government readiness," Disaster Prev. Manag. An Int. J., vol. 13, no. 2, pp. 140-152, 2004. 